Pengaruh Pelatihan Terhadap Kinerja dengan..... (Citra Neza \& Harif Amali Rivai)

\title{
PENGARUH PELATIHAN TERHADAP KINERJA DENGAN MOTIVASI KERJA SEBAGAI VARIABEL MEDIASI PADA KARYAWAN PT. $X$
}

\author{
Citra Neza \\ Magister Manajemen, Fakultas Ekonomi, Universitas Andalas, Indonesia \\ citranezal6@gmail.com \\ Harif Amali Rivai \\ Fakultas Ekonomi, Universitas Andalas, Indonesia \\ harifamali@gmail.com
}

\begin{abstract}
Abstrak
Penelitian ini bertujuan untuk mengetahui pengaruh pelatihan terhadap kinerja. Pengaruh motivasi kerja sebagai variabel mediasi juga diperiksa. Penelitian ini dilakukan pada karyawan PT. X. Data dikumpulkan dari 186 orang karyawan tetap PT. X. Data dikumpulkan melalui survei lapangan dengan menggunakan kuesioner. Hasil data dari survei dianalisis menggunakan software SmartPLS. Hasil penelitian mendukung bahwa pelatihan berpengaruh positif signifikan terhadap kinerja karyawan. Motivasi kerja karyawan berpengaruh signifikan terhadap kinerja karyawan. Hasil penelitian juga didukung bahwa pelatihan berdampak positif signifikan pada motivasi kerja. Studi ini menyimpulkan bahwa motivasi kerja karyawan memediasi secara parsial hubungan antara pelatihan karyawan dan kinerja karyawan.
\end{abstract}

Kata Kunci : Kinerja Karyawan, Motivasi Kerja, Pelatihan, Sumber Daya Manusia

\begin{abstract}
This study aims to determine the effect of training on job performance. The effect of work motivation as a mediating variable was also examined. The research was conducted on employees of PT. X. The data gathered from 186 people permanent employees of PT. X. The data was collected through a field survey. The result of the data from survey was analyzed using SmartPLS software. And the result supported that training significantly positive effect on employee job performance. Employee motivation was forming significantly effect on employee job performance. The result of the study was also supported that's training significantly positive impact on motivation. The study concludes that employee motivation partially mediated the relationship between employee training and employee job performance.
\end{abstract}

Keywords : Employee Job Performance, Human Resource, Training, Work Motivation 


\section{PENDAHULUAN}

Karyawan merupakan aset utama dalam perusahaan. Meskipun perkembangan teknologi saat ini dapat menciptakan mesin yang mampu mengganti tugas dan tenaga manusia, namun sumber daya manusia tetap menjadi penggerak inti dari suatu perusahaan. Oleh karena itu, karyawan harus mempunyai standar yang baik secara kualitas maupun kuantitas untuk dapat meningkatkan keunggulan bersaing suatu perusahaan. Kinerja karyawan adalah fungsi dari kemampuan dan motivasi kerja, di mana kemampuan terdiri dari keterampilan, pelatihan dan sumber daya yang diperlukan untuk melakukan tugas dan motivasi kerja digambarkan sebagai kekuatan batin yang mendorong individu untuk bertindak terhadap sesuatu (Ek dan Mukuru, 2013). Menurut (Khan, 2012) Pelatihan diperlukan untuk meningkatkan kinerja karyawan. Jika karyawan dilatih, mereka akan sangat menyadari spesifikasi pekerjaan mereka, keterampilan yang dibutuhkan untuk melakukan pekerjaan dengan baik dan akan dapat menggunakan teknologi baru. Kemudian tingkat motivasi kerja mereka akan meningkat, yang juga akan bermanfaat dalam peningkatan kinerja, lingkungan kerja dan perilaku manajemen juga akan menghasilkan kinerja yang dimaksimalkan yang akan membantu untuk mencapai tujuan organisasi secara efektif.

PT. X sebagai salah satu perusahaan BUMN harus tetap memperhatikan dan meningkatkan kinerja karyawannya. BUMN merupakan perusahaan yang berperan untuk mewujudkan kesejahteraan yang menjadi harapan bagi masyarakat, sehingga kinerja masing-masing karyawan dalam melayani masyarakat dan bekerja sesuai tujuan perusahaan sangat diperhatikan, karena tantangan utama perusahaan sesungguhnya adalah bagaimana menciptakan sumber daya manusia yang dapat menghasilkan kinerja optimal dan mencapai tujuan perusahaan (Karina, 2017). Kehadiran sangat penting untuk memastikan kinerja yang berkelanjutan untuk menyelesaikan tugas yang diperlukan dan menghindari konflik manajemen dan kinerja yang menurun (Root, 2016). Tingkat disiplin karyawan masih cukup rendah dilihat dari data absensi yang didapat penulis. Hal ini mungkin disebabkan oleh kurangnya kesadaran karyawan dalam menegakkan disiplin, dan tanggung jawab dalam melakukan 
absensi baik saat datang dan saat pulang yang akan berujung mempengaruhi kinerja. Hanya saja, pada data absensi yang didapat hanya menampilkan waktu masuk dan pulang karyawan, karena data hanya didapat saat karyawan melakukan absen finger print. untuk keterangan izin, cuti, atau perjalanan dinas tidak dapat ditampilkan. Oleh karena itu, penulis melakukan penelitian lebih lanjut.

Faktor yang mempengaruhi kinerja menurut (mangkunegara, 2000) adalah faktor kemampuan dan faktor motivasi kerja. Saeed (Saeed et al., 2013) mengatakan bahwa kinerja karyawan dipengaruhi oleh orientasi tujuan karyawan, kualitas hubungan antara karyawan dengan pimpinan, hasil dari kinerja dan kepuasan kerja. Oleh karena itu, penelitian ini ditujukan untuk menguji "Pengaruh Pelatihan Terhadap Kinerja Dengan Motivasi Kerja Sebagai Variabel Mediasi Pada Karyawan PT. X”.

\section{Tujuan Penelitian}

Sesuai dengan rumusan masalah di atas, maka tujuan yang ingin dicapai dalam penelitian ini adalah sebagai berikut:

1. Untuk mengetahui pengaruh pelatihan terhadap kinerja karyawan PT. X.
2. Untuk mengetahui pengaruh pelatihan terhadap motivasi kerja karyawan PT. X.

3. Untuk mengetahui pengaruh motivasi kerja terhadap kinerja karyawan PT. X.

4. Untuk mengetahui pengaruh pelatihan terhadap kinerja karyawan yang dimediasi oleh motivasi kerja karyawan PT. X.

\section{$\begin{array}{lll}\text { KAJIAN TEORI } & \text { DAN }\end{array}$ \\ PENGEMBANGAN HIPOTESIS}

Pelatihan untuk Karyawan

Pelatihan merupakan jenis kegiatan yang direncanakan, sistematis dan menghasilkan peningkatan keterampilan, pengetahuan dan kompetensi yang diperlukan untuk melakukan pekerjaan secara efektif (Gordon, 1992 dalam Nassazi, 2013). Sedangkan menurut (Khan, 2012), pelatihan sebagai proses pembelajaran yang melibatkan perolehan pengetahuan, penajaman keterampilan, konsep, aturan, atau perubahan sikap dan perilaku untuk meningkatkan kinerja karyawan. Pelatihan adalah salah satu fungsi sumber daya manusia yang meningkatkan pengetahuan, keterampilan dan mengubah sikap pekerja (Swanson dan Holton, 2008). 


\section{Motivasi Kerja}

Motivasi kerja adalah konsep yang digunakan ketika menggambarkan kekuatan yang bekerja pada dan atau di dalam individu untuk memulai dan mengarahkan perilaku. Motivasi kerja dapat didefinisikan sebagai karakteristik individu yang bersedia melakukan upaya terhadap serangkaian perilaku tertentu (Tabassi dan Bakar, 2009). Motivasi kerja adalah dorongan internal / eksternal yang mempromosikan energi dan keinginan karyawan untuk terus peduli dan berkomitmen pada tugas-tugas mereka dan mengerahkan upaya terus-menerus dalam mencapai tujuan (Mathis et al., 2012). Makin jelas tujuan yang diharapkan atau yang akan dicapai, makin jelas pula bagaimana tindakan motivasi kerja itu dilakukan.

\section{Kinerja}

Kinerja adalah proses yang secara signifikan mempengaruhi keberhasilan organisasi dengan manajer dan peran pekerja untuk bekerja bersama untuk menetapkan harapan, meninjau hasil dan imbalan kinerja (Mondy et al., 1999 dalam Al-Musadieq et al., 2018). Mwita (2000) menjelaskan bahwa kinerja adalah elemen kunci untuk mencapai tujuan organisasi sehingga kinerja meningkatkan efektivitas dan efektivitas organisasi yang membantu pencapaian tujuan organisasi.

\section{Pelatihan dan Kinerja}

Pelatihan adalah intervensi yang direncanakan dan dirancang untuk meningkatkan faktor penentu kinerja pekerjaan individu (Chiaburu dan Teklab, 2005). Nassazi (2013) mengatakan bahwa pelatihan telah terbukti menghasilkan peningkatan kinerja bagi karyawan maupun bagi organisasi dengan secara positif memengaruhi kinerja karyawan melalui pengembangan pengetahuan, keterampilan, kemampuan, kompetensi, dan perilaku karyawan. DeViney dan Sugrue (2004) menemukan bahwa membangun hubungan antara pelatihan dan kinerja organisasi adalah masalah mendesak nomor satu yang dihadapi para profesional pelatihan. Efektivitas program pelatihan adalah sesuatu yang menggambarkan untuk memastikan apakah program pelatihan dijalankan dengan efektif dalam mencapai sasaran yang ingin dituju (Sofyandi, 2008). Kinerja karyawan tergantung pada berbagai faktor. Tetapi faktor yang paling penting dari kinerja karyawan 
adalah pelatihan. Pelatihan penting untuk meningkatkan kemampuan karyawan. Karyawan yang memiliki lebih banyak pengalaman kerja memiliki kinerja yang lebih baik karena ada peningkatan keterampilan \& kompetensi karena lebih banyak pengalaman kerja (Khan et al., 2012). Landa (2018) menjelaskan bahwa melalui pelatihan kompetensi, karyawan dikembangkan dan memungkinkan mereka untuk melaksanakan pekerjaan yang terkait dengan pekerjaan secara efisien, dan mencapai tujuan perusahaan secara kompetitif. Penggunaan simulasi pelatihan adalah untuk meningkatkan dan mengembangkan pembelajaran pada bidang apa pun yang dapat mengarah pada pemahaman yang lebih baik dan komprehensif dan menghasilkan kinerja yang efektif, juga telah digunakan dalam pelatihan keadaan militer dan pengambilan keputusan berdasarkan penerapan pelatihan simulasi (Koh et al., 2008). Maka berdasarkan uraian penelitian di atas dapat dirumuskan hipotesis sebagai berikut:

$H 1$ : Pelatihan mempunyai pengaruh positif dan signifikan terhadap kinerja karyawan PT. X

\section{Pelatihan dan Motivasi}

Perencanaan Manajemen Sumber Daya Manusia meliputi perencanaan organisasi, pengaduan karyawan, dan pengembangan tim. Namun, pelatihan dan motivasi kerja adalah dua bagian utama dari praktik pengembangan tim (Duncan, 1996 dalam Tabassi dan Bakar, 2009). Menurut Nassazi (2013) selama identifikasi kebutuhan pelatihan, ada kebutuhan untuk membuat, mengembangkan, memelihara, dan meningkatkan sistem yang relevan dalam berkontribusi pada ketersediaan orang dengan keterampilan yang diperlukan. Selain itu, program pelatihan harus dirancang untuk kebutuhan yang berbeda-beda. Dalam konteks pelatihan, motivasi kerja dapat memengaruhi kesediaan karyawan untuk menghadiri program pelatihan, untuk mengerahkan energi terhadap program, dan untuk menerapkan apa yang mereka pelajari dalam program ke dalam pekerjaan (Ek dan Mukuru, 2013). Motivasi kerja dapat meningkatkan kesiapan pekerja untuk menghadiri kursus pelatihan dan untuk mentransfer apa yang mereka pahami dari pelatihan dalam pekerjaan mereka (Alsayyed et al., 2019). Manajer harus menggunakan sistem yang membuat karyawan dihargai 
dengan melakukan pekerjaannya dengan baik.

Maka berdasarkan uraian penelitian di atas

dapat dirumuskan hipotesis sebagai berikut:

$H 2$ : Pelatihan mempunyai pengaruh positif dan signifikan terhadap Motivasi kerja karyawan PT. X

\section{Motivasi Kerja dan Kinerja}

Kinerja merupakan suatu fungsi dari motivasi kerja dan kemampuan. Keberhasilan suatu organisasi dalam peningkatan kinerjanya, sangat tergantung pada motivasi kerja para pegawai dalam melaksanakan tugas pekerjaannya. Menurut Uno (2011), motivasi kerja merupakan dorongan internal dan eksternal dalam diri seseorang yang diindikasikan dengan adanya hasrat yang menimbulkan minat serta dorongan untuk mencapai kebutuhan dan harapan serta citacita agar mendapat suatu penghargaan dan penghormatan. Tujuan dari motivasi kerja adalah memberikan semangat kerja kepada setiap pegawai agar pegawai dapat melaksanakan tugasnya secara efektif dan efisien. Dampak yang terjadi apabila di dalam perusahaan tidak ada motivasi kerja, di mana pegawai akan melakukan pekerjaannya dengan biasa saja dan kurang semangat dalam melaksanakan tugasnya (Suaib, 2016). Hanya dengan motivasi kerja yang tinggi, para pegawai melakukan upaya dengan seluruh kemampuan untuk mencapai kinerja yang optimal (Karina, 2017). Organisasi harus memotivasi karyawan mereka untuk memiliki kinerja terbaik atau untuk mencapai tujuan organisasi (Mohamud et al., 2017). Menurut Zlate dan Cucui (2015), yang penting adalah termotivasi dalam mencapai tujuan yang diusulkan. Maka berdasarkan uraian penelitian di atas dapat dirumuskan hipotesis sebagai berikut:

H3 : Motivasi kerja mempunyai pengaruh positif dan signifikan terhadap Kinerja karyawan PT. X

\section{Pelatihan, Motivasi Kerja dan Kinerja}

Faktor yang mempengaruhi kinerja menurut Mathis dan Jackson (2001), yaitu Kemampuan, Motivasi, Dukungan yang diterima, Keberadaan pekerjaan yang dilakukan, dan Hubungan dengan organisasi. Menurut Mangkunegara (2000), faktor yang mempengaruhi kinerja di antaranya yaitu; (1) faktor kemampuan, secara psikologis, kemampuan atau ability pegawai terdiri atas kemampuan potensi (IQ) dan kemampuan 
reality (pegetahuan dan keterampilan); (2) faktor motivasi, motivasi kerja terbentuk dari sikap seorang pegawai dalam menghadapi situasi kerja. Motivasi kerja merupakan kondisi yang menggerakkan diri pegawai terarah untuk mencapai tujuan kerja. Sikap mental merupakan kondisi mental yang mendorong seseorang untuk berusaha mencapai potensi kerja secara maksimal. Kinerja karyawan adalah fungsi dari kemampuan dan motivasi kerja, di mana kemampuan terdiri dari keterampilan, pelatihan dan sumber daya yang diperlukan untuk melakukan tugas dan motivasi kerja digambarkan sebagai kekuatan batin yang mendorong individu untuk bertindak terhadap sesuatu (ek dan mukuru, 2013). Karyawan yang termotivasi mengikuti pelatihan, akan memberikan kontribusi yang baik dalam kinerjanya. Khan (2012) menyimpulkan bahwa ada hubungan positif antara kinerja karyawan, pelatihan dan motivasi. Semua organisasi yang ingin meningkatkan kinerja karyawan mereka harus fokus pada pelatihan karena juga memotivasi karyawan untuk mencapai tingkat kinerja yang lebih tinggi. Jika motivasi kerja meningkat, kinerja individu diharapkan meningkat, sehingga produktivitas organisasi juga akan meningkat. Kinerja karyawan secara langsung didasarkan pada fungsi pelatihan, dengan motivasi kerja dan kinerja karyawan. Lukasik (2018) menyatakan bahwa Sistem pelatihan yang sesuai dengan kebutuhan memungkinkan untuk memaksimalkan potensi karyawan untuk mencapai tujuan organisasi, juga berdampak besar pada sistem motivasi kerja karyawan. Tanpa pengetahuan dan pelatihan atau pelatihan yang benar dan tepat, bahkan karyawan yang paling termotivasi akan dengan cepat menjadi depresi, frustrasi dan tidak produktif (Asim, 2013). Pelatihan membantu menciptakan hasil yang baik dalam kinerja, jika pelatihan baik maka kinerja juga baik. Maka berdasarkan uraian penelitian di atas dapat dirumuskan hipotesis sebagai berikut:

H4 : Motivasi kerja memediasi pengaruh Pelatihan terhadap Kinerja karyawan PT. X

Berdasarkan hipotesis yang diajukan dalam penelitian ini, maka dapat digambarkan model penelitian sebagai berikut: 


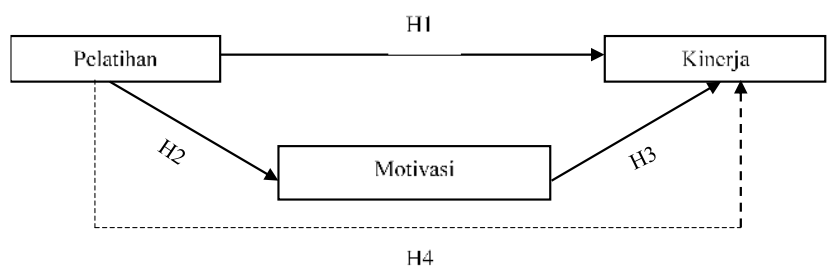

\section{Gambar 1. Model Penelitian}

\section{METODE RISET}

\section{Populasi dan Sampel}

Populasi dalam penelitian ini adalah karyawan tetap PT. X yang berjumlah 186 orang. Pemilihan sampel dalam penelitian ini menggunakan teknik non probability sampling berupa sampel jenuh yang menjadikan seluruh populasi sebagai sampel. Pengumpulan data penelitian menggunakan kuesioner dengan pendistribusian dilakukan melalui bagian administrasi PT. X.

\section{Variabel dan Pengukuran}

Skala pengukuran yang digunakan oleh peneliti untuk menyatakan tanggapan dari responden terhadap setiap pernyataan yang diberikan menggunakan scoring Skala Likert. Skala Likert terdiri dari 5 (lima) skala yaitu Sangat Setuju (SS), Setuju (S), Netral (N), Tidak Setuju (TS) dan Sangat Tidak Setuju (STS). Variabel pelatihan memiliki sembilan item pernyataan yang diadaptasi dari penelitian (Landa, 2018). Variabel motivasi kerja memiliki enam item pernyataan yang diadaptasi melalui 3 item pernyataan dari penelitian Neto, Gomes, \& Silva, (2016) dan tiga item pernyataan dari penelitian Tremblay (Tremblay et al., 2009). Variabel kinerja memiliki 5 item pernyataan yang dikembangkan berdasarkan penelitian Mohamud (Mohamud et al., 2017).

\section{Analisis Data}

Penggunaan PLS, terdapat beberapa evaluasi terhadap model struktural (inner model) dan model pengukuran (outer model). Dalam evaluasi model pengukuran, dilakukan pengujian validitas konvergen (convergent validity), validitas diskriminan (discriminant validity), reliabilitas komposit (composite reliability), dan Average Variance Extracted (AVE). Sedangkan dalam evaluasi model struktural dilakukan uji R-squared $\left(\mathrm{R}^{2}\right)$ dan uji estimasi koefisien jalur. Setelah dilakukan pengujian menggunakan software smart PLS dapat diinterpretasikan berdasarkan hipotesis yang telah dirumuskan sebelumnya. 


\section{HASIL DAN PEMBAHASAN}

\section{Karakteristik Responden}

Karyawan tetap PT. X didominasi oleh jenis kelamin laki-laki dengan presentase sebesar $87,29 \%$ atau 103 orang dan presentase responden perempuan lebih sedikit yaitu, $12,71 \%$ atau 15 orang. Presentase usia terbanyak yaitu berada pada rentang usia 2025 tahun sebesar 54,24\% atau 64 responden, selanjutnya yang berusia 26-30 tahun sebanyak 33 responden atau dengan presentase $27,97 \%$, yang berusia $31-35$ tahun sebanyak 17 responden atau dengan presentase $14,41 \%$, dan jumlah responden terendah dengan usia $>35$ tahun sebanyak 4 responden atau dengan presentase $3,39 \%$. Responden dengan tingkat pendidikan terakhir SMA sebanyak 39 orang atau dengan presentase $33,05 \%$, responden dengan pendidikan terakhir Diploma III sebanyak 27 orang atau dengan presentase $22,88 \%$, responden dengan pendidikan terakhir S1 sebanyak 44 orang atau dengan presentase $37,29 \%$, responden dengan pendidikan terakhir S2 sebanyak 1 orang atau dengan presentase $0,85 \%$ dan responden dengan pendidikan terakhir lainnya sebanyak 7 orang atau dengan presentase $5,93 \%$ yang berpendidikan terakhir DI.

\section{Model Pengukuran (Outer Model)}

\section{Uji Validitas Konvergen}

Tabel 1. Hasil Loading Factor Variabel Penelitian

\begin{tabular}{cccc}
\hline Indikator & Kinerja & $\begin{array}{c}\text { Motivasi } \\
\text { Kerja }\end{array}$ & Pelatihan \\
\hline K1 & 0,888 & & \\
K2 & 0,927 & & \\
K3 & 0,924 & & \\
K4 & 0,913 & & \\
K5 & 0,904 & & \\
M1 & & 0,875 & \\
M2 & & 0,929 & \\
M3 & & 0,894 & \\
M4 & & 0,799 & \\
M5 & & 0,845 & \\
M6 & & 0,732 & \\
P1 & & & 0,857 \\
P2 & & & 0,937 \\
P3 & & & 0,924 \\
P4 & & & 0,901 \\
P5 & & & 0,885 \\
P6 & & & 0,708 \\
P7 & & & 0,902 \\
P8 & & & 0,887 \\
P9 & & 0,902 \\
\hline Sumber: Hasil Olah Data SmartPLS 3.2.8 $(2019)$
\end{tabular}

Pengujian validitas konvergen menggunakan nilai outer loading atau loading factor. Suatu indikator dinyatakan memenuhi validitas konvergen dalam kategori baik apabila nilai outer loading > 0,7. Menurut Chin (1998 dalam Ghozali, 2012), nilai outer loading antara 0,5 - 0,6 sudah dianggap cukup untuk memenuhi syarat validitas konvergen. Terlihat bahwa nilai muatan faktor (loading factor) tahap awal pada Tabel $1 \mathrm{di}$ atas tidak terdapat indikator yang mempunyai faktor loading lebih kecil dari 0,7. Dengan demikian, 
indikator valid dalam mengukur masingmasing variabel latennya dan dapat digunakan untuk analisis lebih lanjut.

\section{Uji Validitas Diskriminan}

Uji validitas diskriminan dilakukan untuk mengetahui seberapa jauh perbedaan nilai validitas suatu variabel bila dibandingkan dengan variabel lainnya. Uji validitas diskriminan menggunakan nilai cross loadings dan Fornell-Larcker Criterion (Henseler, Ringle, \& Sarstedt, 2014). Suatu indikator dinyatakan memenuhi validitas diskriminan apabila nilai cross loading indikator pada variabelnya adalah yang terbesar dibandingkan pada variabel lainnya. Nilai cross loading yang diharapkan adalah lebih besar dari 0,7 (Ghozali dan Latan, 2015).

Berdasarkan Tabel 2, diketahui bahwa Nilai cross loading variabel kinerja dengan indikator $\mathrm{K} 1$ sebesar 0,888 lebih besar dari nilai cross loading indikator $\mathrm{K} 1$ terhadap variabel motivasi kerja $(0,647)$ dan pelatihan $(0,661)$. Begitu juga dengan nilai cross loading vaiabel laten dengan indikator lainnya. Berdasarkan hasil yang diperoleh tersebut, dapat dinyatakan bahwa indikator-indikator yang digunakan dalam penelitian ini telah
Tabel 2. Cross Loadings

\begin{tabular}{rrrr}
\hline & \multicolumn{1}{l}{ Kinerja } & \multicolumn{2}{l}{ Motivasi } \\
\multicolumn{1}{l}{ Kerja } & \multicolumn{1}{l}{ Pelatihan } \\
\hline K1 & $\mathbf{0 , 8 8 8}$ & 0,647 & 0,661 \\
K2 & $\mathbf{0 , 9 2 7}$ & 0,678 & 0,651 \\
K3 & $\mathbf{0 , 9 2 4}$ & 0,708 & 0,670 \\
K4 & $\mathbf{0 , 9 1 3}$ & 0,711 & 0,643 \\
K5 & $\mathbf{0 , 9 0 4}$ & 0,701 & 0,692 \\
M1 & 0,656 & $\mathbf{0 , 8 7 5}$ & 0,405 \\
M2 & 0,755 & $\mathbf{0 , 9 2 9}$ & 0,517 \\
M3 & 0,708 & $\mathbf{0 , 8 9 4}$ & 0,542 \\
M4 & 0,589 & $\mathbf{0 , 7 9 9}$ & 0,441 \\
M5 & 0,644 & $\mathbf{0 , 8 4 5}$ & 0,383 \\
M6 & 0,447 & $\mathbf{0 , 7 3 2}$ & 0,398 \\
P1 & 0,606 & 0,471 & $\mathbf{0 , 8 5 7}$ \\
P2 & 0,654 & 0,475 & $\mathbf{0 , 9 3 7}$ \\
P3 & 0,625 & 0,421 & $\mathbf{0 , 9 2 4}$ \\
P4 & 0,649 & 0,445 & $\mathbf{0 , 9 0 1}$ \\
P5 & 0,696 & 0,546 & $\mathbf{0 , 8 8 5}$ \\
P6 & 0,561 & 0,460 & $\mathbf{0 , 7 0 8}$ \\
P7 & 0,650 & 0,483 & $\mathbf{0 , 9 0 2}$ \\
P8 & 0,635 & 0,428 & $\mathbf{0 , 8 8 7}$ \\
P9 & 0,673 & 0,474 & $\mathbf{0 , 9 0 2}$ \\
\hline Sumber: Hasil Olah Data & & & \\
& &
\end{tabular}

memiliki validitas diskriminan yang baik dalam menyusun variabelnya masing-masing.

Selain mengamati nilai cross loading, metode lain untuk menilai validitas diskriminan adalah dengan Fornell-Larcker Criterion yang membandingkan nilai akar kuadrat dari Average Variance Extracted (AVE) setiap konstruk dengan korelasi antara konstruk lainnya dalam model (Henseler et al., 2014). Apabila nilai akar kuadrat average variance extracted (AVE) untuk masingmasing indikator dipersyaratkan lebih besar 
dari 0,7 dan lebih besar dari nilai korelasi dengan seluruh variabel laten lainnya, maka dikatakan memiliki validitas diskriminan yang baik. Direkomendasikan nilai pengukuran AVE harus lebih besar dari 0,50 (Sarwono dan Narimawati, 2015). Tabel 3 menunjukkan bahwa nilai AVE dari keseluruhan variabel laten berkisar antara 0,719 sampai 0,831 artinya bahwa nilai AVE seluruh variabel lebih besar dari 0,5 .

Nilai akar kuadrat AVE (fornell-larcker criterion) pada tabel 4 menunjukkan bahwa nilai akar kuadrat AVE seluruh variabel lebih besar dari 0,7. Hasil tersebut menunjukkan bahwa seluruh variabel laten yang digunakan dalam penelitian ini mempunyai validitas diskriminan yang baik.

Tabel 4 menunjukkan nilai akar kuadrat AVE (Fornell-Larcker Criterion) pada variabel kinerja sebesar 0,911 yang lebih besar dari nilai korelasi antara variabel kinerja dengan variabel lainnya yaitu sebesar 0,757 (Tabel 4). Nilai akar kuadrat AVE pada motivasi kerja sebesar 0,848 lebih besar dari nilai korelasi antara variabel motivasi kerja dengan variabel lainnya yaitu sebesar 0,757 (Tabel 4). Nilai akar kuadrat AVE pada variabel pelatihan sebesar 0,880 (Tabel 4).
Tabel 3. Nilai AVE

\begin{tabular}{|c|c|c|c|c|}
\hline & 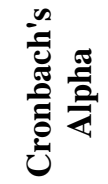 & $\begin{array}{l}\varangle_{1} \\
\stackrel{2}{2}\end{array}$ & 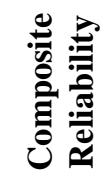 & 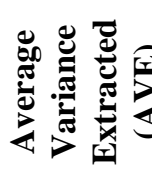 \\
\hline Kinerja & 0,949 & 0,949 & 0,961 & 0,831 \\
\hline $\begin{array}{l}\text { Motivasi } \\
\text { Kerja }\end{array}$ & 0,921 & 0,934 & 0,939 & 0,719 \\
\hline Pelatihan & 0,963 & 0,965 & 0,969 & 0,775 \\
\hline
\end{tabular}

Tabel 4. Fornell-Larcker Criterion \& Latent Variable Correlations

\begin{tabular}{lccc}
\hline & Kinerja & $\begin{array}{c}\text { Motivasi } \\
\text { Kerja }\end{array}$ & Pelatihan \\
\hline Kinerja & 0,911 & - & - \\
Motivasi & 1,000 & 0,757 & 0,728 \\
Kerja & 0,757 & 0,848 & - \\
Pelatihan & 0,757 & 1,000 & 0,532 \\
& 0,728 & 0,532 & 0,880 \\
\hline
\end{tabular}

Sumber: Hasil Olah Data SmartPLS 3.2.8 (2019)

Nilai tersebut lebih besar dari nilai korelasi antara variabel pelatihan dengan variabel lainnya yaitu sebesar 0,728 (Tabel 4). Dengan demikian nilai akar kuadrat AVE lebih besar dari nilai korelasi antar variabel lainnya. Artinya bahwa seluruh variabel laten dalam penelitian ini mempunyai validitas diskriminan yang baik.

\section{Reliabilitas komposit}

Reliabilitas komposit merupakan reliabilitas untuk mengukur seberapa mampu indikator dapat mengukur konstruk latennya. Reliabilitas ini menggunakan koefisien reliabilitas untuk menjelaskan model pengukuran yang diuji. Koefisien ini 
merupakan koefisien konsistensi internal yang mendekati nilai koefisien internal Cronbach's alpha. Nilai Reliabilitas komposit 0,6 - 0,7 dianggap memiliki reliabilitas yang baik dan kelompok indikator yang mengukur sebuah variabel memiliki reliabilitas komposit yang baik jika memiliki reliabilitas komposit $\geq 0,7$ meskipun bukan merupakan standar absolut (Ghozali dan Latan, 2015). Hasil reliabilitas komposit dipaparkan pada Tabel 5.

Tabel 5 menunjukkan bahwa nilai reliabilitas komposit seluruh variabel laten berkisar antara 0,939 dan 0,969. Artinya, keseluruhan nilai reliabilitas komposit lebih besar dari 0,7. Hasil ini menunjukkan bahwa seluruh variabel laten mempunyai reliabilitas komposit yang baik.

\section{Evaluasi Model Struktural (Inner Model)}

\section{Uji kesesuaian model (Goodness of fit)}

Uji kesesuaian model berdasarkan kriteria yang ditetapkan yang dinamakan dengan Goodness of Fit. Goodness of Fit dari Inner Model diukur menggunakan R-square variabel laten dependen dengan interpretasi yang sama dengan regresi. Koefisien determinasi ( $\mathrm{R}^{2}$ ) merupakan cara untuk menilai seberapa besar konstruk endogen
Tabel 5. Composite Reliability

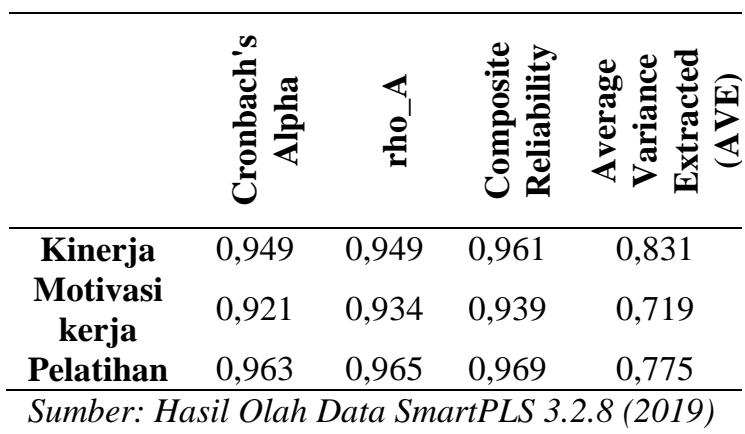

dapat dijelaskan oleh konstruk eksogen. Nilai koefisien determinasi ( $\mathrm{R}^{2}$ ) diharapkan antara 0 dan 1 . Nilai $\mathrm{R}^{2}$ yang dapat diterima, masingmasing dengan $0,75,0,50,0,25$, yang menggambarkan tingkat akurasi prediksi yang substansial, sedang, atau lemah. Nilai RSquare merupakan hasil (berupa persentase) atas representasi variabel independen terhadap variabel dependen.

Berdasarkan nilai R-Square yang tertera pada Tabel 6 dapat dijelaskan bahwa:

1. Variabel kinerja dapat dijelaskan oleh variabel motivasi kerja dan pelatihan sebesar 72,0 persen sisanya 28 persen dijelaskan oleh variabel-variabel lainnya yang tidak diteliti.

2. Variabel motivasi kerja dapat dijelaskan oleh variabel pelatihan sebesar 28,3 persen, sisanya dijelaskan oleh variabelvariabel lainnya yang tidak diteliti. 
Tabel 6. Nilai R Square

\begin{tabular}{ccc}
\hline & R Square & R Square Adjusted \\
\hline $\begin{array}{c}\text { Kinerja } \\
\text { Motivasi } \\
\text { Kerja }\end{array}$ & 0,720 & 0,715 \\
\hline Sumber: Hasil Olah Data SmartPLS 3.2.8 (2019)
\end{tabular}

\section{Uji hipotesis model koefisien jalur}

Berdasarkan olah data yang telah dilakukan, hasilnya dapat digunakan untuk menjawab hipotesis pada penelitian ini. Uji hipotesis pada penelitian ini dilakukan dengan melihat nilai T-Statistics dan nilai P-Values. Prosedur bootstrapping menghasilkan nilai tstatistik untuk setiap jalur hubungan yang digunakan untuk menguji hipotesis. Nilai $\mathrm{t}$ statistik tersebut akan dibandingkan dengan nilai $\mathrm{t}$ tabel. Variabel eksogen dinyatakan berpengaruh secara signifikan terhadap variabel endogen jika nilai $\mathrm{t}$ statistik $>\mathrm{t}$ tabel. $\mathrm{t}$ tabel harus di atas 1,960 untuk hipotesis twotailed dan di atas 1,645 untuk hipotesis onetailed untuk menguji hipotesis pada alpha 5 persen (Hair et al., 2001). Penelitian ini menggunakan uji hipotesis one tailed, di mana hubungan yang diuji terarah kepada positif sehingga menggunakan parameter $\mathrm{t}$ tabel 1,645. Jika nilai t-statistik lebih kecil dari nilai t-tabel ( t-statistik < 1.645 ), maka Ho diterima dan Ha ditolak. Jika nilai t-statistik lebih besar
Tabel 7. Hasil Path Coefficient model jalur

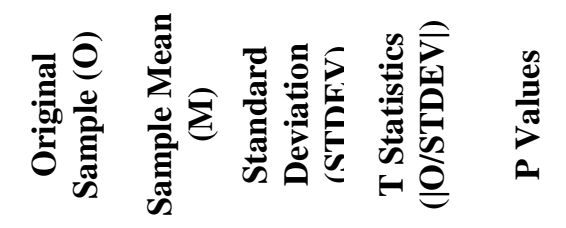

\begin{tabular}{|c|c|c|c|c|c|}
\hline $\begin{array}{c}\text { Pelatihan } \\
\rightarrow \\
\text { Kinerja }\end{array}$ & 0,515 & 0,511 & 0,077 & 6,708 & $\mathbf{0 , 0 0 0}$ \\
\hline $\begin{array}{c}\text { Pelatihan } \\
\rightarrow \\
\text { Motivasi } \\
\text { Kerja }\end{array}$ & 0,454 & 0,455 & 0,076 & 5,994 & $\mathbf{0 , 0 0 0}$ \\
\hline $\begin{array}{c}\text { Motivasi } \\
\text { Kerja } \rightarrow \\
\text { Kinerja }\end{array}$ & 0,532 & 0,538 & 0,081 & 6,613 & $\mathbf{0 , 0 0 0}$ \\
\hline
\end{tabular}

Tabel 8. Hasil Specific Indirect Effects model jalur

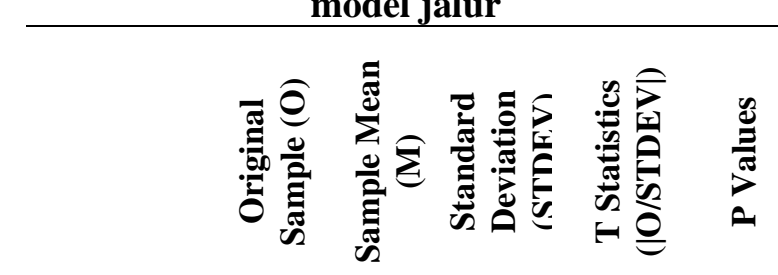

\begin{tabular}{llllll}
\hline $\begin{array}{c}\text { Pelatihan } \\
\rightarrow\end{array}$ & & & & & \\
$\begin{array}{c}\text { Motivasi } \\
\text { Kerja } \rightarrow \\
\text { Kinerja }\end{array}$ & 0,274 & 0,273 & 0,046 & 5,914 & $\mathbf{0 , 0}$ \\
\hline
\end{tabular}

Sumber: Hasil Olah Data SmartPLS 3.2.8 (2019)

atau sama dengan t-tabel ( $\mathrm{t}$-statistik $>1.645$ ), maka Ho ditolak dan Ha diterima ( Ghozali dan Latan, 2015). Hipotesis penelitian dapat dinyatakan diterima apabila nilai P-Values < 0,05. Hasil uji hipotesis dipaparkan pada Tabel 7 dan 8.

Pengujian Hipotesis 1: Nilai sample mean sebesar 0,511 maka pelatihan berpengaruh positif terhadap kinerja karyawan PT. X. Semakin baik kualitas pelatihan maka akan 
meningkatkan kinerja karyawan. Nilai t statistik sebesar 6,708 lebih besar dari t tabel $(1,645)$, nilai $\mathrm{P}$ value sebesar $0,000<0,05$ maka $\mathrm{H}_{1}$ diterima dan $\mathrm{H}_{0}$ ditolak. Artinya, pelatihan memiliki pengaruh terhadap kinerja karyawan PT. X.

Pengujian Hipotesis 2: Nilai sample mean sebesar 0,455 maka pelatihan berpengaruh positif terhadap motivasi kerja karyawan PT. X. Semakin baik kualitas pelatihan maka akan meningkatkan motivasi kerja karyawan. Nilai t statistik sebesar 5,994 lebih besar dari t tabel $(1,645)$, nilai $\mathrm{P}$ value sebesar $0,000<0,05$ maka $\mathrm{H}_{2}$ diterima dan $\mathrm{H}_{0}$ ditolak. Dengan demikian, pelatihan memiliki pengaruh terhadap motivasi kerja karyawan PT. X.

Pengujian Hipotesis 3: Nilai sample mean sebesar 0,538 maka motivasi kerja berpengaruh positif terhadap kinerja karyawan PT.X. Semakin tinggi motivasi kerja maka akan meningkatkan kinerja karyawan. Nilai t statistik sebesar 6,613 lebih besar dari t tabel $(1,645)$, nilai $\mathrm{P}$ value sebesar $0,000<0,05$ maka $\mathrm{H}_{3}$ diterima dan $\mathrm{H}_{0}$ ditolak. Artinya, motivasi kerja memiliki pengaruh terhadap kinerja karyawan PT. X.
Hipotesis 4: Berdasarkan tabel 8 Nilai sample mean sebesar 0,273 maka motivasi kerja memediasi pengaruh pelatihan terhadap kinerja secara positif. Semakin baik kualitas pelatihan dan motivasi kerja, maka akan meningkatkan kinerja karyawan. Nilai t statistik sebesar 5,914 lebih besar dari t tabel $(1,645)$, nilai $\mathrm{P}$ value sebesar $0,000<0,05$ maka $\mathrm{H}_{0}$ ditolak dan $\mathrm{H}_{4}$ diterima. Artinya, motivasi kerja memediasi pengaruh pelatihan terhadap kinerja karyawan PT. X.

pengaruh tidak langsung

$\mathrm{VAF}=$ pengaruh langsung + pengaruh tidak langsung

0,728

$\mathrm{VAF}=$

$$
0,511+0,728
$$

$\mathrm{VAF}=58,76 \%$

Jika nilai VAF di atas $80 \%$, maka menunjukkan peran variabel mediasi sebagai pemediasi penuh (full mediation). Variabel mediasi dikategorikan sebagai pemediasi parsial apabila nilai VAF berkisar antara $20 \%$ sampai dengan $80 \%$, namun jika nilai VAF kurang dari $20 \%$ dapat disimpulkan bahwa hampir tidak ada efek mediasi. Nilai VAF pada penelitian ini sebesar $58,76 \%$ 
menunjukkan bahwa motivasi kerja memediasi pelatihan terhadap kinerja karyawan PT. X secara parsial.

\section{Pengaruh Pelatihan Terhadap Kinerja}

\section{Karyawan}

Pelatihan berpengaruh positif terhadap kinerja karyawan PT. X. Pengaruh signifikan antara pelatihan dan kinerja tidak terlepas dari indikator kuesioner yang mendapatkan nilai tinggi dan profil rensponden. Seperti pada indikator pernyataan nomor 2 di kuesioner pelatihan, "Pelatihan membantu saya memuaskan pelanggan dengan layanan berkualitas". Indikator ini mendapat nilai ratarata terbilang tinggi, yang artinya pelatihan yang diikuti karyawan telah membantu dalam memuaskan pelanggan. Ketika pelanggan puas, secara tidak langsung kinerja dapat dikatakan meningkat. Semakin baik kualitas pelatihan maka akan meningkatkan kinerja karyawan. kualitas pelatihan yang diberikan oleh PT. X sudah baik, karena berhasil memberikan pelayanan yang baik sehingga dapat memuaskan pelanggan. Selain itu pada pernyataan indikator pelatihan nomor 3 "Pelatihan meningkatkan kinerja perusahaan" mendapatkan nilai tinggi lainnya. Dapat disimpulkan bahwa pelatihan telah banyak memberikan efek positif terhadap perusahaan seperti dalam kepuasan karyawan dan memuaskan pelanggan. Dilihat dari sisi profil responden, terdapat $70 \%$ lebih karyawana yang memiliki masa kerja di bawah 50 bulan, atau masih kurang dari dari 5 tahun. Perjalanan karir karyawan yang masih panjang, pelatihanpelatihan yang diikuti masih belum cukup. Masih banyak jenis pelatihan yang belum diikuti untuk dapat mendorong kinerja yang lebih baik. Profil responden dari sisi pendidikan terakhir, rata-rata $55 \%$ atau lebih lulusan D3 dan SMA sehingga masih banyak membutuhkan tambahan skill dan pengetahuan mengenai core business perusahaan yang lebih luas. Dilihat dari profil responden dengan usia rata-rata sebesar $70 \%$ didominasi oleh karyawan yang berusia di bawah 30 tahun. Usia muda atau usia produktif dapat lebih cepat menangkap pelajaran pelatihan yang diberikan.

Pelatihan berpengaruh positif terhadap kinerja karyawan PT. X. Setiap peningkatan persepsi responden tentang pelatihan maka kinerja karyawan akan meningkat. Semakin baik kualitas pelatihan maka akan meningkatkan kinerja karyawan. Hal ini mendukung penelitian sebelumnya yang 
dilakukan oleh Nassazi (2013) bahwa

pelatihan telah terbukti menghasilkan

peningkatan kinerja bagi karyawan maupun

bagi organisasi dengan secara positif memengaruhi kinerja karyawan melalui pengembangan pengetahuan, keterampilan, kemampuan, kompetensi, dan perilaku karyawan. Jika seorang karyawan tidak berkinerja baik maka organisasi perlu mengidentifikasi faktor yang perlu diperbaiki apakah ada kebutuhan pelatihan atau kurangnya kemampuan karyawan untuk melakukan tugas (Sohail, Safdar, Saleem, Ansar, dan Azeem, 2014).

\section{Pengaruh Pelatihan Terhadap Motivasi}

\section{Kerja Karyawan}

Pelatihan berpengaruh positif terhadap motivasi kerja karyawan PT. X. Pengaruh signifikan antara pelatihan dan motivasi kerja tidak terlepas dari indikator kuesioner yang mendapatkan nilai tinggi. Dilihat dari indikator pernyataan yang membentuk motivasi kerja nomor 6 "Saya melakukan pekerjaan ini untuk kepuasan yang saya dapatkan ketika saya berhasil melakukan tugas-tugas sulit". Kepuasan terhadap keberhasilan ini besar pengaruhnya terhadap keberhasilan karyawan. Semakin baik kualitas pelatihan yang dilakukan oleh PT. X maka akan meningkatkan motivasi kerja karyawan baik dalam mengikuti pelatihan maupun saat selesai mengikuti pelatihan. Semakin baik kualitas pelatihan yang dilakukan oleh PT. X maka akan meningkatkan motivasi kerja karyawan baik dalam mengikuti pelatihan maupun saat selesai mengikuti pelatihan.

Hal ini membuktikan bahwa menurut Sohail Khan (2019), Pelatihan dan pengembangan meningkatkan motivasi kerja individu untuk melakukan pekerjaannya dengan baik. Menurut Alsayyed et al. (2019) Motivasi kerja dapat meningkatkan kesiapan pekerja untuk menghadiri kursus pelatihan dan untuk mentransfer apa yang mereka pahami dari pelatihan dalam pekerjaan mereka. Selain itu Asim (2013) juga menyatakan tanpa pengetahuan dan pelatihan atau pelatihan yang benar dan tepat, bahkan karyawan yang paling memotivasi akan dengan cepat menjadi depresi, frustrasi dan tidak produktif. Selanjutnya juga mendukung penelitian Khan (2012) dan penelitian Ek dan Mukuru (2013) yang menyatakan pelatihan berpengaruh positif terhadap motivasi kerja karyawan. Kesempatan pelatihan yang diberikan PT. X pada karyawan menjadikan karyawan merasa 
diberi peluang untuk maju dan upgrade kemampuan yang dimiliki.

\section{Pengaruh Motivasi Kerja Terhadap}

\section{Kinerja Karyawan}

Motivasi kerja berpengaruh positif terhadap kinerja karyawan PT. X. Pengaruh signifikan antara motivasi kerja dan kinerja tidak terlepas dari indikator kuesioner yang mendapatkan nilai tinggi. Indikator motivasi kerja nomor 3 menyatakan "Saya punya banyak energi untuk menyemangati diri saya di tempat kerja". Hal ini yang dapat berperan untuk memotivasi karyawan sehingga kinerja karyawan dapat meningkat dan karyawan dapat mengatasi hal-hal sulit yang dihadapi dalam pekerjaannya. Hal ini memperkuat penelitian terdahulu dari Mohamud et al. (2017) yang menyatakan Organisasi harus memotivasi karyawan mereka untuk memiliki kinerja terbaik atau untuk mencapai tujuan organisasi.

Jika motivasi kerja meningkat, kinerja individu diharapkan meningkat, sehingga produktivitas organisasi juga akan meningkat (Al-Musadieq et al., 2018). Menurut Teori Maslow, motivasi kerja diilustrasikan sebagai kerucut; bahwa orang akan termotivasi jika kebutuhan mereka seperti target hidup mereka sepenuhnya tercapai mulai dari kebutuhan fisiologis hingga kebutuhan aktualisasi diri (Mullins, J.L, 2005). PT. X sudah baik dalam memenuhi kebutuhan karyawannya. Setiap enam bulan sekali dilakukan penilaian terhadap kinerja karyawan yang hasil penilaiannya akan dikonversikan menjadi reward kinerja. Hal ini tentunya dapat menjadi salah satu motivasi kerja karyawan untuk meningkatkan kinerja mereka menjadi lebih efektif dan efisien.

\section{Pengaruh pelatihan tehadap kinerja dengan motivasi sebagai mediasi}

Motivasi kerja memediasi pengaruh pelatihan terhadap kinerja secara positif. Setiap peningkatan persepsi responden tentang pelatihan maka kinerja akan meningkat dengan motivasi kerja sebagai mediasi. Semakin baik kualitas pelatihan dan motivasi kerja maka akan meningkatkan kinerja karyawan. Nilai VAF menunjukkan bahwa motivasi kerja memediasi pelatihan terhadap kinerja karyawan PT. X secara parsial. Ini berarti, terdapat efek tidak langsung yang diberikan motivasi kerja pada pelatihan, karena masih tetap berpengaruh terhadap 
meningkatnya kinerja. Karyawan

menggunakan program pelatihan yang

berbeda untuk mencari pengalaman belajar

dan mendapatkan perubahan permanen

yang mengarah pada kinerja yang baik

(Stephen dan David, 2004).

Hal ini mendukung penelitian AlMusadieq et al. (2018) tentang motivasi kerja adalah variabel mediasi pada pengaruh desain pekerjaan terhadap kinerja sumber daya manusia. Hal ini menunjukkan bahwa semakin tinggi motivasi kerja akan mengakibatkan semakin tinggi pengaruh desain pekerjaan terhadap kinerja sumber daya manusia. Penelitian ini juga didukung oleh (Alsayyed et al., 2019) dan (Dysvik dan Kuvaas, 2008) tentang pengaruh motivasi kerja dalam memediasi pelatihan dan kinerja karyawan. (Cunningham dan Mahoney, 2004) mencoba untuk menyelidiki peran komitmen organisasi, valensi pelatihan dan motivasi pelatihan dalam sekelompok atletik perguruan tinggi, dan menemukan bahwa motivasi pelatihan berfungsi sebagai mediator antara komitmen dan valensi dan kemanjuran diri pasca pelatihan. Di sini, motivasi memiliki peran yang berpengaruh terhadap selfefficacy. (Patterson et al., 2004) (dalam Carol
Yeh-Yun Lin, 2012) melaporkan bahwa persepsi psikologis iklim kreativitas organisasi cenderung mempengaruhi motivasi kerja karyawan untuk menghasilkan ide-ide baru, hal inilah yang mengemukakan pentingnya menguji peran mediasi yang mungkin dari motivasi kerja dalam model kinerja. Terbukti bahwa pelatihan itu penting dan berpengaruh terhadap core bisinis yang dijalankan PT. X Pelatihan yang telah diikuti oleh karyawan PT. X memberikan dampak yang baik dari sisi motivasi kerja dan kinerja karyawan.

\section{KESIMPULAN DAN SARAN}

Berdasarkan studi ini, ditemukan bahwa: (1) Pelatihan terbukti berpengaruh positif dan signifikan terhadap kinerja karyawan PT. X. Ketika kualitas pelatihan ditingkatkan, maka akan diikuti oleh peningkatan kinerja; (2) Pelatihan juga terbukti berpengaruh positif dan signifikan terhadap motivasi kerja karyawan PT. X. Setiap peningkatan persepsi responden tentang pelatihan maka motivasi kerja karyawan akan meningkat; (3) Motivasi kerja terbukti berpengaruh positif dan signifikan terhadap kinerja karyawan PT. X Jika motivasi kerja 
karyawan meningkat, maka kinerja karyawan

meningkat; (4) Motivasi kerja terbukti

memiliki peran mediasi secara parsial terhadap

hubungan antara pelatihan dan kinerja

karyawan PT. X. Semakin baik kualitas

pelatihan dan motivasi kerja maka akan

meningkatkan kinerja karyawan.

Berdasarkan hasil penelitian di atas, terdapat beberapa implikasi sebagai berikut:

1. Pelatihan, indikator pernyataan kuesioner pelatihan nomor 6 menyatakan "Pelatihan memberi saya taktik baru untuk mengatasi tantangan yang saya hadapi ketika melakukan tugas saya". Serta indikator nomor 5 "Pelatihan memberi saya keterampilan dan pengetahuan yang diperlukan untuk melaksanakan pekerjaan saya sebaik mungkin, yang meningkatkan kinerja dan kualitas pekerjaan”. Mendapat nilai yang rendah dibanding indikator lainnya. oleh sebab itu, harus didesain pelatihan yang relevan untuk dapat meningkatkan keterampilan dan pengetahuan karyawan. seperti misalnya memberikan pelatihan bagaimana menghadapi tantangan yang dihadapi, atau problem solving. Indikator pernyataan pelatihan nomor 9 "Pelatihan membantu saya menggunakan peralatan kerja dengan benar, memanfaatkan teknologi canggih dan mengamati praktik kesehatan dan keselamatan yang benar". juga mendapatkan nilai rata-rata yang lebih rendah dibading indikator lainnya. Perusahaan dapat memberikan pelatihan skill teknis yang masih dirasa kurang. Untuk dapat mencegah pemborosan waktu dan sumber daya lainnya. upgrading pelatihan yang berhubungan dengan peralatan berteknologi tinggi atau peralatan yang lebih canggih mengikuti perkembangan.

2. Dengan penulis melakukan penelitian ini, dapat memotivasi perusahaan untuk melakukan evaluasi di bidang SDM agar tetap selalu memberikan pelatihan yang berkualitas, baik dari sisi materi yang diberikan maupun motivasi kerja yang menarik karyawan untuk 
mengikuti pelatihan yang

dilaksanakan. Namun, dengan tidak

mengesampingkan pelatihan dan

motivasi kerja bagi kinerja

karyawan divisi SDM sendiri dan

perancang pelatihan bagi karyawan

lainnya.

3. Kinerja karyawan PT. X dapat ditingkatkan dengan perlu memperhatikan motivasi kerja karyawan maupun pelatihanpelatihan yang diberikan.

Berdasarkan hasil penelitian, frekuensi pelatihan dapat ditambah untuk menambah skill dan potensi karyawan. Secara berkala dilakukan analisis kebutuhan pelatihan untuk dapat mengurangi pelatihan yang kurang efektif dan meningkatkan kualitas pelatihan dengan memberikan metode serta jenis pelatihan mengikuti perkembangan core bisnis PT. X.

4. Motivasi, indikator pernyataan motivasi kerja nomor 1 menyatakan "Saya memiliki keinginan besar untuk melakukan pekerjaan saya". Mendapat nilai yang rendah dibanding indikator lainnya.

Perusahaan dapat mencari solusi

bagaimana membangkitkan semangat internal karyawannya. indikator nomor 4 "Saya melakukan pekerjaan ini, karena saya mendapatkan banyak kesenangan dari mempelajari hal-hal baru". Hasil nilai rata-rata yang didapat, karyawan masih belum cukup senang dalam mempelajari hal baru. Perusahaan harus menciptakan suasana kerja seperti merancang bagaimana agar pekerjaan yang dilakukan dapat disukai karyawan. Motivasi kerja internal karyawan perlu disadarkan terhadap pentingnya menimbulkan semangat demi mencapai peningkatan karir yang lebih baik. Misalnya, dapat mendatangkan motivator profesional atau motivational speech.

Keterbatasan dan saran penelitian yang dilakukan penulis agar dapat dijadikan sumber ide dan saran untuk penelitian masa yang akan datang antara lain adalah : 1) Pengumpulan data yang dilakukan hanya berdasarkan 
kuesioner yang diisi responden, penulis tidak mengamati secara langsung kinerja dan program pelatihan yang berlangsung pada PT. X. Untuk penelitian selanjutnya disarankan peneliti juga melakukan wawancara pada bagian SDM maupun karyawan terkait; 2) Penelitian hanya membahas secara umum pengaruh pelatihan terhadap kinerja melalui motivasi kerja sebagai mediasi. Peneliti dapat menyarankan penelitian selanjutnya, untuk melihat pengaruh motivasi kerja karyawan untuk mengikuti dan selama menjalankan pelatihan serta melihat faktor instrinsik dan ekstrinsik motivasi. Serta mengembangan variabel lainnya; 3) Jumlah responden penelitian hanya dilakukan kepada 186 karyawan tetap PT. X. Responden penelitian selanjutnya ditinjau dari unit PT. X yang berbeda maupun jenis perusahaan berbeda. 


\section{DAFTAR PUSTAKA}

A.A. Anwar Prabu Mangkunegara ,2000. Manajemen Sumber Daya Manusia. Bandung. PT, Remaja Rosdakarya.

Al-Musadieq, M., Nurjannah, N., Raharjo, K., Solimun, S., \& Achmad Rinaldo Fernandes, A. (2018). The mediating effect of work motivation on the influence of job design and organizational culture against HR performance. Journal of Management Development, 37(6), 452-469.

Alsayyed, N., Sweis, R. J., El-Mashaleh, M., \& Albalkhy, W. (2019). The Effects of Training and Motivating Employees on Improving Performance of Construction Companies The Case of Jordan, (May).

Asim, M. (2013). Impact of Motivation on Employee Performance with Effect of Training: Specific to Education Sector of Pakistan. International Journal of Scientific and Research Publications.

Carol Yeh-Yun Lin, F.-C. L. (2012). A cross-level analysis of organizational creativity climate and perceived innovation.

Chiaburu, D. S., Teklab, A. G. (2005). Individual and contextual influences on multiple dimensions of training effectiveness. Journal of European Industrial Training, 20, 282-290.

DeViney, N., \& Sugrue, B. (2004). Learning Outsourcing: A Reality Check, Training \& Development.

Dysvik, A., \& Kuvaas, B. (2008). The relationship between perceived training opportunities, work motivation and employee outcomes.

Ek, K., \& Mukuru, E. (2013). Effect of Motivation on Employee Performance In Public Middle Level Technical Training Institutions In Kenya.

Ghosh, P., Joshi, J. P., Satyawadi, R., Mukherjee, U., \& Ranjan, R. (2014). Evaluating effectiveness of a training programme with trainee reaction. 
Henseler, J., Ringle, C. M., \& Sarstedt, M. (2014). A new criterion for assessing discriminant validity in variance-based structural equation modeling. Journal of the Academy of Marketing Science, $43(1), 115-135$.

Sofyandi, Herman,. 2008. Manajemen Sumber Daya Manusia. Yogyakarta : Graha Ilmu.

Karina, N. (2017). Analisis pengaruh kompetensi dan motivasi terhadap kinerja karyawan pt. pln (persero) kantor distribusi wilayah lampung.

Khan, M. I. (2012). The Impact of Training and Motivation on Performance of Employees.

Landa, E. (2018). Influence of Training on Employees Performance in Public Institution in Tanzania, $8(2), 324-336$.

Lukasik, K. (2018). The Impact of Training on Employees Motivation in SMEs Industry. Eukasik, Katarzyna, 28(1), 96-109.

Mangkunegara, A. P., \& Agustine, R. (2016). Effect of Training, Motivation and Work Environment on Physicians' Performance. Academic Journal of Interdisciplinary Studies, 5(1), 173-188.

Mathis, M. A. De, Diniz, J. B., Hounie, A. G., Shavitt, G., Fossaluza, V., Ferrão, Y., \& Leckman, J. F. (2012). Trajectory in Obsessive-Compulsive Disorder Comorbidities.

Mohamud, S. A., Ibrahim, A. A., \& Hussein, J. M. (2017). The Effect of Motivation on Employee Performance: Case Study in Hormuud Company in Mogadishu Somalia, (November).

Mwita, John Isaac., 2000. Performance Management Model, A systems-based approach to public service quality. International Journal of Public Sector Management, International Development Department, University of Birmingham, UK.

Nassazi, A. (2013). Effects of training on employee performance. Evidence from Uganda. Business Economics and Tourism, 1-57.

Neto, M. L. M. de C. M. T. R., Gomes, C. A. A. F., \& Silva, J. F. da. (2016). Values, Motivation, Commitment, Performance and Rewards: Analysis Model. 
Ngala, F. B. J. A., \& Odebero, S. O. (2010). Teachers' perceptions of staff development programmes as it relates to teachers' effectiveness: A study of rural primary schools in Kenya. Educational Research and Reviews, 5(1), 1-9.

Root. J. N, 2016, How Employees With Poor Attendance Affect the Workplace, Chron. [Online]

Available through: http://smallbusiness.chron.com/employees-poor-attendance-affect-

workplace-11517.html [Accessed 13th Jun 2016]

Root. J. N, 2016, How Employees With Poor Attendance Affect the Workplace, Chron.

Saeed, R., Mussawar, S., Lodhi, R. N., Iqbal, A., Nayab, H. H., \& Yaseen, S. (2013). Factors affecting the performance of employees at work place in the banking sector of Pakistan. Middle East Journal of Scientific Research, 17(9), 1200-1208.

Sohail, A., Safdar, R., Saleem, S., Ansar, S., \& Azeem, M. (2014). Effect of Work Motivation and Organizational Commitment on Job Satisfaction: (A Case of Education Industry in Pakistan). Global Journal of Management And Business Research, 14(6), 41-46.

Sohail Khan, N. N. A. (2019). The impact of staff training and development on teachers' productivity, (May).

Swanson, R. A., \& Holton, E. F. (2008). Foundations of Human Resource Development (First Edition).

Tabassi, A. A., \& Bakar, A. H. A. (2009). Training, motivation, and performance: The case of human resource management in construction projects in Mashhad , Iran. International Journal of Project Management, 27(5), 471-480.

Tremblay, M. A., Blanchard, M., Taylor, S., Pelletier, L. G., \& Villeneuve, M. (2009). Work Extrinsic and Intrinsic Motivation Scale: Its Value for Organizational Work Extrinsic and Intrinsic Motivation Scale : Its Value for Organizational Psychology Research, (October). 
Pengaruh Pelatihan Terhadap Kinerja dengan..... (Citra Neza \& Harif Amali Rivai)

Uno, H.(2011). Teori Motivasi dan Pengukurannya. Jakarta: PT Bumi Aksara Bandung PT Remaja Rosdaka Karya.

Zlate, S., \& Cucui, G. (2015). Motivation and performance in higher education. Procedia - Social and Behavioral Sciences, 180(November 2014), 468-476. 